\title{
IDENTIFICATION OF ERRORS IN STUDENTS' PRONUNCIATION USING THE PRINCIPLE OF APPROXIMATION IN THE TEACHING OF PRONUNCIATION, THE STUDY OF THE NEGATIVE IMPACT OF THE UZBEK LANGUAGE ON THEIR ORIGIN AND THE ELIMINATION OF EXISTING PRONUNCIATION PROBLEMS
}

\author{
Gulhayo Farhod Qizi Baratova
}

Lecturer National Institute Of Art And Design Named After Kamoliddin Behzod Of The Academy Of Arts Of Uzbekistan Tashkent, Uzbekistan

\section{ABSTRACT}

This article was composed to improve showing English elocution. The point is to study the angles that impact the language learning measure. Subsequently, we need to investigate some basic troubles that Uzbek understudies experience while learning the way to express English sounds. The article covers various continuous articulation troubles that mess up Uzbek students of English. These challenges incorporate tense and remiss vowels, consonant endings, stress and tones. It is a valuable reference hotspot for the two educators and understudies who need to improve their way to express English.

KEYWORDS: - Pronunciation, teaching technologies, problems in pronunciation, consonants, vowels, innovative methods, intonation, sound framework.

\section{INTRODUCTION}

A great many unfamiliar understudies need to learn English as well as could reasonably be expected. For example, it is just a matter of perusing and composing it, and they will discover no assistance here. In any case, numerous students need to have the option to communicate in English well, with an elocution which can be effectively perceived by both different students and English individuals. Language begins with the ear.

\section{THE MAIN FINDINGS AND RESULTS}

At the point when an infant begins to talk, he does it by hearing the sounds his mom makes and impersonating them. On the off chance that a child is brought into the world hard of hearing he can't hear these sounds and hence can't mimic them and won't talk. In any case, typical infants can hear and can mimic. They are magnificent imitators, and this endowment of impersonation, which gives us the endowment of discourse, goes on for various years. It is notable that an offspring of ten years of age or less can become familiar with any language impeccably, in the event that it is raised encircled by that language, regardless of where it was conceived or who its folks were. In any case, after this age the capacity to copy impeccably turns out to be less, and we as a whole know very well indeed that grown-ups have extraordinary trouble in acing the way to express foreign languages. A few 
CURRENT RESEARCH JOURNAL OF PHILOLOGICAL SCIENCES 2(10): 27-

31, October 2021

DOI: https://doi.org/10.37547/philological-crjps-02-10-06

ISSN 2767-3758

(C)2021 Master Journals

Crossref do

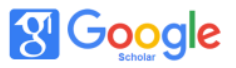

Accepted19th October, 2021 \& Published 24 ${ }^{\text {th }}$ October, 2021

students are more skilled than others, they find articulating different dialects less troublesome, however they never discover them simple. For what reason is it so? For what reason should this blessing that we as a whole have as youngsters vanish later in our life? For what reason can't grown-up individuals get the trademark sound of a foreign language as a kid can? The response to this is our local language won't let us. When we are grown up the propensities for our own language are solid to such an extent that they are exceptionally hard to break. In our own language we have a genuinely modest number of sound-units which we set up in a wide range of blends to shape the words and sentences we utilize each day. What's more, as we get more seasoned, we are overwhelmed by this modest number of units. It seems as though we had in our minds a specific fixed number of boxes for sounds. At the point when we tune in to our own language we hear the sounds and we put each into the correct box, and when we talk we go to the crates and take out the sounds we need in the request we need them [1].

Furthermore, as we do this throughout the years the crates get more grounded and more grounded until all that we hear, regardless of whether it is our own language or another, must be placed into one of these cases, and all that we state emerges from English boxes contain the sounds toward the start of the words balance, meager, and sin, that is $f$, th and s. As kids progress through the disclosure of language in their initial three years, there are unsurprising examples in the rise and advancement of numerous highlights of the language they are learning. For instance, kids don't utilize worldly modifiers, for example, "tomorrow" or "a week ago" until they build up some comprehension of time. Students of English frequently hope to have the option to communicate in that language like a local speaker. In any case, they experience numerous elements to pick up their craving. One of the normal factors that they find troublesome is the way to express another sound framework. Students find that their native language impacts their way to express English. And furthermore, we can see a few issues on consonant sounds. Particularly Uzbek students of English will have a few troubles in the way to express sounds which don't exist in the local language. For example, /s/and/z/ is viewed as confusable in utilization. The students articulate/s/rather than/z/, so a word, for example, peas is articulated as harmony. Subsequently, the significance will likewise be changed. What's more, a few consonants are composed yet not articulated. This is either on the grounds that they were once articulated (thump) or originate from a foreign language (brain science).

Plus, we have a ton of articulation botches in the consonant sounds/ $\theta /$ and/ð/. Varying these sounds are hard for Uzbek students as well. Speakers regularly make an intensely voiceless stop/t/rather than a voiceless fricative/ $\theta /$ in a word like thank. Clearly, they express the sound/t/in light of their language since in rudimentary level students the letter th is consolidated by an intensely suctioned/t/. Along these lines, the word three can be articulated precisely like tree. Rudimentary level students of English generally produce/d/or/z/for/ð/sounds, so the word than may seem like/dæn/or/zæn/. In the Uzbek language, the voiceless stop/p/doesn't happen in introductory situation of words. What's more, our speakers can substitute a voiced stop/b/or a voiceless fricative/f/for/p/. Subsequently, the word pool may seem as though nitwit, and pop may seem as though bop. Conversely, in the last positions, these consonants regularly incite disarray for students. For instance, lab may seem as though lap. Then again, actually there is an issue with linguistic consummation s. At the point when words end in $\mathrm{s}$ in types of consonant-vowel-consonant, the/s/sound is much of the time precluded. For 
CURRENT RESEARCH JOURNAL OF PHILOLOGICAL SCIENCES 2(10): 27-

31, October 2021

DOI: https://doi.org/10.37547/philological-crjps-02-10-06

ISSN 2767-3758

(C2021 Master Journals

Crossref do

8 Google

Accepted19th October, 2021 \& Published 24th October, 2021

models, sits may go to/sit/and needs may become/wan/. In some cases, our speakers will in general exclude both/t/and/s/sound in the word needs. Some other last consonant groups, for example, /kt/as in strolled,/t/as in washed,/d/as in judged, and /ld/ as in filled are extremely hard for our rudimentary level students to articulate. To explain, the words world might be articulated as/w/, myself might be articulated as /mayse/. These missteps can be exceptionally hard for our students to survive. A few speakers go over different challenges in learning English articulation. The confusions of vowels, especially among tense and vowels in English can be difficult to learn. Furthermore, the contrasts between consonant positions, consonant bunches lead rudimentary level students of English to meet an enormous number of troubles [2]. Thus, our speakers regularly go over articulation issues when conveying in English. Penny Ur in his book "A course in language educating" proposes the accompanying instructing thoughts to use in instructing articulation:

- Dictation: of irregular arrangements of words, of words that have

- comparative spelling issues, of complete sentence, of half-sentence to be

- finished.

- Reading so anyone might hear: of syllables, words, phrases, sentences.

- Prediction: direct a lot of words in the objective language the students don't

- known at this point, however whose spelling concurs with rules.

The consequences of trial held among novices in the English language learning show that cycle of articulating phonemes effectively ought to be practiced in three stages: 1) to articulate consonant and vowel sounds which don't exist in the Uzbek language independently. For instance, consonants [ð, $\theta, \mathrm{r}, \mathrm{w}, \mathrm{f}, \mathrm{v}]$ and vowels [u, ou, ai, ue]. 2) to articulate the words with voiced consonant toward the end [b, d, g, v,]. 3) To articulate "comparable" (consonants which exist in both English and Uzbek dialects) in phrases [m, g, b, s, z, n. d, p, t, k,]. [6] Learning the way to express a few words are joined with the level of simple and troublesome sounds. That implies some English sounds are hard to articulate. The instructor articulates one sound and this way is named "saying discourse sounds" and "listening sounds by rudimentary level students" level. The students should focus on the substance of expression and ought to comprehend its significance of that new word or expression. Rudimentary level students must tune in and afterward see those sounds.

The role of technology in teaching pronunciation. Prior employments of PCs in elocution showing zeroed in altogether on the recognizable proof (regularly alluded to as 'discourse/voice acknowledgment') and creation of individual phonemes. Segmental methodologies keep on being created. For instance, the SPECO Project, another framework utilizing progressed discourse innovation in the clinical remediation of youngsters' discourse pathology, is being researched for its potential in L2 elocution educating. Boersma and Weenink have built up the PRAAT Program to show vowel and diphthong creation by methods for formant plotting and which is accessible gratis on www.praat.org. Then again, Derwing et al. (2000), find in their investigation into mainstream programmed programming acknowledgment (ASR) bundles for ESL discourse, that such bundles are as yet not ready to proceed just as human audience members tuning in to non-local discourse, and they presume that "the opportunities for utilizing ASR programming in the L2 study hall are charming" yet that it must be painstakingly assessed to guarantee that it perceives non-local discourse and sensible precision levels (to maintain a strategic distance 
CURRENT RESEARCH JOURNAL OF PHILOLOGICAL SCIENCES 2(10): 27-

31, October 2021

DOI: https://doi.org/10.37547/philological-crjps-02-10-06

ISSN 2767-3758

(C)2021 Master Journals

Crossref do

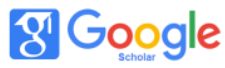

Accepted19th October, 2021 \& Published 24 ${ }^{\text {th }}$ October, 2021

from pointless amendment and disappointment) just as people do. One further utilization of innovation in elocution instructing is the in the field of word references. Huge numbers of the significant distributers have as of late started giving CD-ROMs with their word references. Like the other innovative advances delineated over, these, as well, advance student independence in the obtaining of elocution. For instance, they offer students a scope of highlights, for example, the chance to hear words in seclusion and, now and again, in associated discourse, and the chance of recording and tuning in to themselves so as to contrast their own elocution and the word reference adaptation. Much more helpful regarding self-access elocution is the most recent release of Daniel Jones' English Pronouncing Dictionary with CD-ROM, which likewise gives plentiful subtleties of both North American and British English elocution. The other manner by which innovation is demonstrating helpful in articulation instructing is by empowering scientists to gather corpora with which they can try out and, if important, 'expose' prior cases which had been founded on instinct instead of experimental proof. So far, the test to business as usual has included two fundamental wonders: last pitch and stress-timing. The two Levis in regard of American English and Caudwell in regard of British English have come to comparative end results about conclusive pitch. Following in the strides of Fries (1964) presumably the main corpus-based investigation of inquiry inflection (Roach, individual correspondence) - both gathered exact information from local speakers of the particular assortments of English (instead of the developed models supported by before articulation specialists) and dissected them for definite contribute course yes/no inquiries. In neither one of the cases did the since quite a while ago held conviction that the pitch has a rising tone (carefully, a fall-rise) instead of a falling tone face assessment, however so far hardly any instructors or materials essayists have reacted to the finding [7].

\section{Conclusion}

Taking everything into account, the slip-ups made by Uzbek students in articulating English sounds might be amended by educator bit by bit dependent on some notable hypotheses and practices. The exercises of English will be more profitable if the instructors consider the above given proposition in making educational program and exercise plans. The examination plans talked about in this part have without a doubt prompted a restored enthusiasm for articulation as a significant ability in second language instructing and learning. Elocution, it appears, has recovered a great part of the standing it held in the times of the Reform Movement from the get-go in the only remaining century. The exploration has empowered it to reappear, however, as a more adaptable and more significant language marvel, ready to adjust to its setting of utilization and to relate in both educating and examination to other semantic zones, most remarkably (yet not solely) talk and sociolinguistics. The way that two elocution works were shortlisted for the esteemed BAAL (British Association of Applied Linguistics) Book Prize in the previous three years, and that TESOL Quarterly is right away to distribute an issue committed to elocution is proof, if such was required, that articulation has grown up and is probably not going to stay on the edges of language educating in the twenty-first century as it accomplished for a significant part of the last aspect of the 20th.

\section{ReFERENCES}

1. J. D. O'Connor "Better English Pronunciation" Cambridge University Press. Second edition. 1980. p.70.

2. Patsy M. Lightbown, Nina Spada "How 
CURRENT RESEARCH JOURNAL OF PHILOLOGICAL SCIENCES 2(10): 27 -

31, October 2021

DOI: https://doi.org/10.37547/philological-crjps-02-10-06

ISSN 2767-3758

(C)2021 Master Journals

Crossref do

(8) Google

Accepted19th October, 2021 \& Published 24th October, 2021

Languages are Learned" Oxford University Press. Third edition 2010. p.2.

3. Frederika Gebhard "English Pronunciation" The second edition 2010-2011. p. 14

4. Nguyen Tien Dung, Faculty of Foreign Languages, the professor of Ba Ria - Vung Tau University, from his lecture

5. Marion Williams, Tony Wright "A Course in Language Teaching" Cambridge University Press. First edition, 1999. p.22.

6. Jamol Jalolov. "Methods of teaching foreign languages". Toshkent 1996. pp. 178.179.

7. Bamgbose, A. (1998). "Torn between the norms: innovations in world Englishes'. World Englishes 17,1, 1-14.

8. Beebe, L. \& Giles, H. (1984). 'Speechaccommodation theories: a discussion in terms of second-language acquisition'. In $\mathrm{H}$. Giles (Ed.) International Journal of the Sociology of Language. The Dynamics of Speech Accommodation. Amsterdam: Mouton.

9. Bent T. \& Bradlow, A. (2003). 'The interlanguage speech intelligibility benefit'. Journal of the Acoustical Society of America 114, 1600-1610.

10. Bowler, B. \& Cunningham, S. (1999). Headway Pronunciation Course. Oxford: Oxford University Press.

11. Bradford, B. (1996, Summer). 'Upspeak'. Speak Out! Newsletter of the IATEFL Pronunciation Special Interest Group, 18, 2224.

12. Bradford, B. (1988). Intonation in Context. Cambridge: Cambridge University Press.

13. Brazil, D. (1997). The communicative value of intonation in English. Cambridge: Cambridge University Press.

14. Brazil, D., Coulthard, M., \& Johns, C. (1980). Discourse Intonation and Language Teaching. London: Longman.

15. Brett, D. (2002). 'Improved Vowel Production with the PRAAT Programme'. In D.Teeler (Ed.).

16. Brown, A. (1997). Use of English in Teaching. Singapore: Prentice Hall.

17. Brown, A., Deterding, D., \& Low, E.L. (2000).The English Language in Singapore. Research on Pronunciation. Singapore: Singapore Association of Applied Linguistics.

18. Burton J. \& Clennell, C. (Eds.) (2003). Interaction and Language Learning. Alexandria, VA: TESOL.

19. Bekchanovna, T. S. (2019). Constitutional and legal regulation of mass media and study of public opinion. Вопросы науки и образования, (23 (71)).

20. Zakirova, S. A., Pîrvan, L. R., \& Zunnunova, U. G. (2020). CHALLENGES AND PROSPECTS IN ART HIGHER EDUCATION OF UZBEKISTAN AND ROMANIA. European Journal of Research and Reflection in Educational Sciences (EJRRES), 8, 10.

21. Kultashev, B., Sadikova, S., \& Kultasheva, N. (2021). Development of Portrait of Uzbekistan During the Early 20thCentury. Journal of Contemporary Issues in Business and Government, 27(2), 2040-2053.

22. Sayfullaev, N. (2019). Current Issues on Fine ARTS Education: Continuity and Prospects for Development. Religación, 4, 192-194. 